\title{
KUALITAS DAN KESUKAAN BAKSO IKAN NILA (Oreochromis niloticus) DENGAN PENAMBAHAN EKSTRAK KAROTENOID DARI CANGKANG UDANG PUTIH (Litopenaeus vannamel)
}

\section{THE QUALITY AND PREFERENCE OF TILAPIA (oreochromis niloticus) MEATBALLS SUPPLEMENTED WITH CAROTENOID EXTRACT FROM WHITE SHRIMP SHELL (litopenaeus vannamei)}

\author{
Iin Patricia Hayon Paliling ${ }^{1}$, Metusalach ${ }^{1}$, dan Nursinah Amir ${ }^{1}$ \\ ${ }^{1}$ Program Studi Pemanfaatan Sumberdaya Perikanan, Fakultas Ilmu Kelautan dan Perikanan, Universitas \\ Hasanuddin
}

Diterima: 06 Januari 2019; Disetujui: 03 Maret 2019

\begin{abstract}
ABSTRAK
Penelitian ini dilakukan pada bulan Mei hingga Juni 2018. Penelitian ini bertujuan untuk mengetahui karakteristik kualitas organoleptik dan tingkat preferensi konsumen bakso nila yang dilengkapi dengan ekstrak karotenoid dari kulit udang putih (Litopenaeus vannamei). Penelitian ini dilakukan dengan menggunakan metode eksperimental desain acak lengkap dengan empat perlakuan berbeda. Percobaan dilakukan dalam dua tahap. Pada tahap pertama, kadar ekstrak karotenoid yang digunakan adalah 0,2 g, sedangkan pada tahap kedua adalah $2,0 \mathrm{~g}$. Rasio daging nila dengan pati yang digunakan dalam pembuatan bakso nila adalah: $A=70: 30+$ karotenoid; $B=60: 40+$ karotenoid; $C=50: 50+$ karotenoid; dan $D=70: 30+$ tanpa karotenoid sebagai kontrol. Hasil penelitian menunjukkan kualitas bakso nila yang dibuat dalam penelitian ini sesuai dengan Standar Nasional Indonesia (SNI 7266: 2014) untuk bakso ikan. Bakso nila yang dilengkapi dengan ekstrak karotenoid lebih disukai oleh panelis dibandingkan yang lain tanpa karotenoid. Preferensi panelis terbaik diberikan kepada bakso nila yang menggunakan $50 \%$ daging nila dengan penambahan ekstrak karotenoid cangkang udang putih.
\end{abstract}

Kata kunci: bakso, ikan nila, ekstrak, karotenoid cangkang udang putih.

\begin{abstract}
This research was conducted from May to June 2018. This study was aimed to determine the characteristics of organoleptic quality and the level of consumer preference of tilapia meatballs supplemented with carotenoid extract from the shell of white shrimp (Litopenaeus vannameI). The study was conducted using an experimental method involving a completely randomized design with four diffrent treatments. The experiment was carried out in two stages. In the first stage, the level of carotenoid extract used was $0,2 \mathrm{~g}$, while in the second stage was $2,0 \mathrm{~g}$. The ratio of tilapia meat to starch used in the making of tilapia meatballs were: $A=70: 30$ + carotenoid; $B=60: 40$ + carotenoid; $C=50: 50$ + carotenoid; and $D=$ 70:30 + no carotenoid as a control. The results showed the quality of tilapia meatballs that made in this study were correspond with the Indonesian National Standards (SNI 7266: 2014) for fish meatballs. The tilapia meatballs supplemented with carotenoid extracts were preferred by panelists compared to the others with
\end{abstract}


no carotenoids. The best preference of the panelists was given to the tilapia meatballs that used $50 \%$ of tilapia meat with the addition of white shrimp shell carotenoid extract.

Key words: meatballs, tilapia, extracts, white shrimp shell carotenoids.

\section{Contact person : Iin Patricia Hayon Paliling \\ E-Mail \\ : iinpaliling23@gmail.com}

\section{PENDAHULUAN}

Bakso merupakan salah satu produk olahan yang digemari masyarakat. Bakso dapat dibuat dari daging sapi, ayam dan ikan. Pada umumnya bakso yang ada di masyarakat berbahan dasar daging sapi. Bakso daging sapi mengandung kolesterol yang tinggi yaitu 74 $\mathrm{mg} / 100 \mathrm{~g}$. Kolesterol adalah salah satu jenis lemak yang dapat menimbulkan penyakit apabila jumlahnya berlebihan di dalam tubuh. Kandungan lemak yang terdapat pada daging sapi sebanyak 1,5\%-13\% (Permatasari dan Wina, 2002).

Mahalnya harga daging sapi untuk pembuatan bakso merupakan salah satu alasan diperlukan alternatif sumber protein yang lebih murah. Alternatif sumber protein hewani yang saat ini memungkinkan untuk dikembangkan dalam pembuatan bakso adalah ikan nila. Ikan nila merupakan ikan konsumsi yang umum hidup di perairan tawar dan di perairan payau. Ikan nila dipilih sebagai bahan baku karena memiliki daging yang tebal, kompak dan mudah dipisahkan dari tulang-tulang dan durinya. Selain itu, ikan nila memiliki kadar lemak $4,1 \%$ dan termasuk ikan berlemak sedang, sehingga sesuai digunakan untuk bahan baku bakso ikan (Astawan, 2004).

Selama ini masyarakat Indonesia memanfaatkan limbah kulit udang hanya terbatas untuk pakan ternak, pembuatan terasi dan kerupuk. Sementara itu masih banyak limbah kulit udang yang dibuang dan dibiarkan membusuk. Jika limbah tersebut tidak ditangani secara tepat, akan menimbulkan dampak negatif bagi lingkungan. Limbah kulit dapat dimanfaatkan karena mengandung senyawa karotenoid, terutama dalam bentuk pigmen warna merah astaxanthin.

Astaxanthin merupakan salah satu pigmen karotenoid alami yang banyak ditemukan pada hewan laut terutama ikan salmon dan golongan krustasea. Astaxanthin juga merupakan anti oksidan bagi manusia karena mempunyai gugus radikal yang dapat melindungi tubuh terhadap proses peroksidasi lipid dan kerusakan akibat proses-proses 
oksidasi pada membran sel dan jaringan tubuh sehingga bisa menghambat proses penuaan (Fitria dkk., 2014).

Sebelumnya sudah banyak peneliti yang melakukan penelitian mengenai bakso ikan nila. Diantaranya yaitu pembuatan bakso ikan nila dengan perbandingan cangkang kepala udang dengan air dan mengetahui pengaruh penyimpanan selama 4 minggu pada suhu chilling $0-6^{\circ} \mathrm{C}$ (Aditya, 2002), pemanfaatan karagenan (Euchema cottoni) sebagai emulsifier terhadap kestabilan bakso ikan nila (Oreochromis nilotichus) pada penyimpanan suhu dingin (Fitria dkk., 2014). Pada penelitian kali ini, peneliti melakukan pembuatan bakso ikan nila dengan proporsi daging ikan nila yang berbeda yaitu 50\%, 60\% dan 70\% dengan konsentrasi karotenoid yang sama.

Dengan mengekstrak karotenoid dari Iimbah kulit udang ini, diharapkan dapat memberikan nilai tambah bagi produk bakso ikan nila serta penerimaan konsumen terhadap bakso ikan nila (Oreochromis niloticus) lebih meningkat dengan penambahan karotenoid dari cangkang udang putih (Litopenaeus vannamei).

\section{DATA DAN METODE}

Penelitian dilaksanakan pada bulan Mei Juni 2018 di Laboratorium Teknologi Hasil Perikanan, Fakultas Ilmu Kelautan dan
Perikanan Universitas Hasanuddin. Metode yang digunakan dalam penelitian adalah metode eksperimen. Melakukan percobaan pembuatan bakso ikan nila dengan penambahan ekstrak karotenoid dari cangkang udang.

\section{Rancangan Percobaan}

Rancangan yang digunakan adalah Rancangan Acak Lengkap (RAL) dengan empat perlakuan yang berbeda, 2 kali percobaan diulang sebanyak 3 kali. Percobaan pertama menggunakan 0,2g karotenoid dan percobaan kedua menggunakan 2,0g karotenoid.Keempat perlakuan berbeda yang dilakukan yaitu: Perlakuan $A=70 \%$ proporsi daging ikan nila, $30 \%$ tepung kanji dan karotenoid; Perlakuan B $=60 \%$ proporsi daging ikan nila, 40\% tepung kanji dan karotenoid; Perlakuan C = $50 \%$ proporsi daging ikan nila, 50\% tepung kanji dan karotenoid; Perlakuan D $=70 \%$ proporsi daging ikan nila, 30\% tepung kanji tanpa karotenoid. Dari empat perlakuan ini, banyaknya proporsi bumbu yang digunakan sama.

\section{Prosedur Penelitian}

\section{Penyiapan Cangkang Udang Putih}

Sebanyak $4 \mathrm{~kg}$ cangkang udang putih yang diambil dari PT. BOMAR dibersihkan dari sisa-sisa dagingnya lalu dicuci dengan air tawar dan dikeringkan menggunakan oven dengan suhu $70^{\circ} \mathrm{C}$ selama 6 jam. Setelah kering, 
cangkang udang dihaluskan menggunakan blender agar komponen dalam cangkang udang yang akan diekstrak lebih mudah terekstrak.

2. Ekstraksi Karotenoid Cangkang Udang Putih

Karotenoid dari cangkang udang putih yang telah diblender diekstraksi menggunakan metode maserasi (perendaman dalam larutan pengekstrak) dengan pelarut pengekstrak etanol $96 \%$ selama 24 jam dengan pengadukan secara berkala. Rasio cangkang udang - pelarut yang digunakan adalah 1:3 (b/v). Setelah maserasi, ekstrak cangkang udang disaring menggunakan kertas saring Whatman No.1, dan filtrat yang diperoleh dikeringkan dengan menguapkan pelarut etanol 96\% menggunakan rotary evaporator. Selanjutnya ekstrak cangkang udang yang telah dipisahkan dari etanol dimasukkan ke dalam corong pisah (separatory funnels) dan dicampurkan dengan larutan heksana untuk memisahkan karotenoid cangkang udang dengan asam amino, protein dan zat-zat lain yang ikut terekstrak. Hasil ekstrak selanjutnya disimpan dalam lemari pendingin (kulkas) sampai digunakan untuk membuat bakso ikan nila.

\section{Penyiapan Ikan Nila}

Ikan nila sebanyak 30 ekor diambil dari PPI Paotere Makassar. Ikan nila dibersihkan dan dicuci menggunakan perasan air jeruk nipis, dibelah membujur (fillet) kemudian diambil daging, lalu dibilas lagi dengan perasan air jeruk nipis. dimasukkan ke dalam wadah kemudian dimasukkan ke dalam frezeer.

\section{Pengolahan Bakso Ikan Nila}

Daging ikan dicampur dengan tepung kanji, karotenoid, karagenan dan bahan/bumbu lainnya. Campuran bahan dicampur secara merata menggunakan mixer hingga adonan menjadi kalis. Adonan dibentuk menjadi bulatan (bola) secara manual dengan menggunakan tangan dan sendok. Bakso hasil cetakan ditampung pada wadah yang berisi air hangat dengan suhu $60^{\circ} \mathrm{C}$ selama \pm 20 menit. Selanjutnya bakso direbus pada suhu $90^{\circ} \mathrm{C}$ selama \pm 30 menit atau sampai bakso mengapung. Setelah matang, bakso diangkat dan didinginkan lalu dilakukan uji organoleptik dan uji hedonik.

\section{Uji Organoleptik}

Uji organoleptik dilakukan untuk mengetahui kualitas suatu produk berdasarkan Standar Nasional Indonesia. Parameter yang diamati adalah kenampakan, bau, rasa dan tekstur dari produk yang dinilai oleh 30 panelis. Penilaian tersebut menggunakan SNI bakso ikan dan diberi nilai dalam score sheet.

6. Uji Hedonik / Kesukaan

Uji hedonik dilakukan untuk mengetahui tingkat kesukaan panelis terhadap suatu produk. Selain diminta tanggapan tentang suka 
atau tidak, panelis juga diminta untuk mengemukakan tingkat kesukaannya dalam score sheet uji penerimaan konsumen terhadap 5 parameter yaitu kenampakan, bau, rasa, tekstur dan warna yang dinilai oleh 30 panelis. Skala hedonik yang digunakan yaitu nilai 1 jika tidak suka, 2 jika netral dan 3 jika suka.

\section{Analisis Data}

Data hasil penelitian dianalisis menggunakan Anova. Perbedaan antar perlakuan dianalisa menggunakan Uji Tukey. Pengaruh perlakuan dan perbedaan antar perlakuan ditetapkan pada tingkat kepercayaan 95\% $(\alpha=0.05)$. Data ditampilkan dalam bentuk gambar dan grafik.

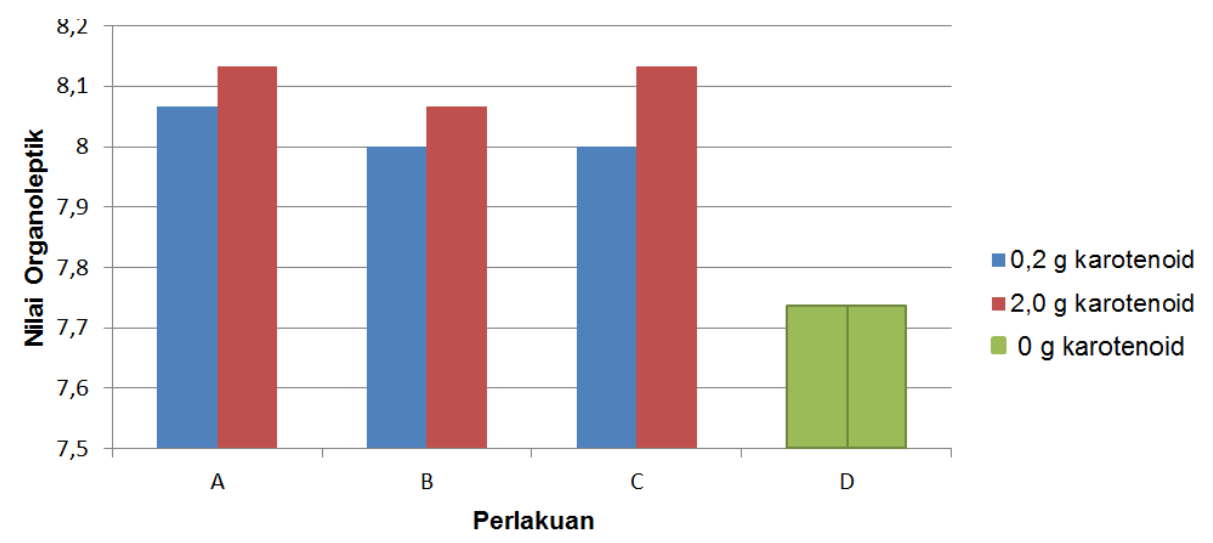

Gambar 1. Nilai Organoleptik Kenampakan Bakso Ikan Nila dengan Penambahan Ekstrak Karoteoid dari Cangkang Udang (Perbandingan daging ikan: kanji, $A=70: 30, B=60: 40, C=50: 50, D=70: 30$ tanpa karotenoid)

Gambar 1 memperlihatkan bahwa nilai organoleptik kenampakan bakso ikan nila dengan penambahan ekstrak karotenoid dari cangkang udang berkisar antara 7.73-8.13. Nilai organoleptik yang terendah ditemukan pada perlakuan tanpa penambahan karotenoid

\section{HASIL DAN PEMBAHASAN}

\section{A. Kualitas Organoleptik Bakso Ikan Nila}

Parameter organoleptik yang diuji pada penelitian ini terdiri dari uji terhadap kenampakan, bau, tekstur, dan warna dengan nilai sebagai berikut:

\section{Kenampakan}

Nilai organoleptik kenampakan bakso ikan nila dengan penambahan ekstrak karoteoid dari cangkang udang dapat dilihat pada Gambar 1. 
7). Berdasarkan SNI 7266:2014 hal tersebut menandakan bahwa bakso ikan memiliki kriteria permukaan agak halus, tidak berongga dan cerah.

Menurut Dewi (2007), kenampakan bakso ikan yang baik haruslah berbentuk bulat, halus, berukuran seragam, bersih, cemerlang dan tidak kusam. Secara umum, bakso ikan nila dengan penambahan ekstrak karotenoid dari cangkang udang hasil penelitian telah memenuhi kriteria tersebut namun bentuknya yang tidak bulat halus dan ukurannya yang kurang seragam. Hal ini dikarenakan pembentukan bakso ini dilakukan secara manual dengan menggunakan tangan. Hasil uji anova menunjukkan kenampakan bakso ikan nila dengan proporsi daging ikan yang berbeda pada penambahan 0,2 g ekstrak karotenoid tidak berbeda nyata namun penambahan ekstrak karotenoid menghasilkan nilai kenampakan yang signifikan lebih baik dibandingkan bakso yang tidak diberi ekstrak karotenoid (Lampiran 3). Begitupula pada penambahan 2,0 g ekstrak karotenoid tidak memberikan perbedaan yang signifikan pada bakso yang proporsi dagingnya berbeda (Lampiran 4) tetapi mampu meningkatkan nilai kenampakan lebih baik dibanding pada penambahan 0,2 gram ekstrak karotenoid dan tanpa penambahan karotenoid (Gambar 1). Pada hasil uji T test menunjukkan bahwa tidak ada pengaruh bakso pada proporsi daging dan kanji 70:30, 60:40 dan 50:50 terhadap penambahan rasio karotenoid $0,2 \mathrm{~g}$ dan $2,0 \mathrm{~g}$ pada kenampakan bakso ikan nila (Lampiran 5).

\section{Bau}

Penilaian aroma dilakukan dengan cara mencium langsung bakso ikan hasil penelitian. Pada Gambar 2 terlihat bahwa nilai organoleptik pada bau bakso ikan nila dengan penambahan ekstrak karotenoid dari cangkang udang berkisar antara 7.80-8.46. Nilai terendah ditemukan pada proporsi daging ikan nila $70 \%$ menggunakan 2,0 g karotenoid sedangkan untuk nilai tertinggi pada proporsi daging ikan nila $70 \%$ tidak menggunakan karotenoid.

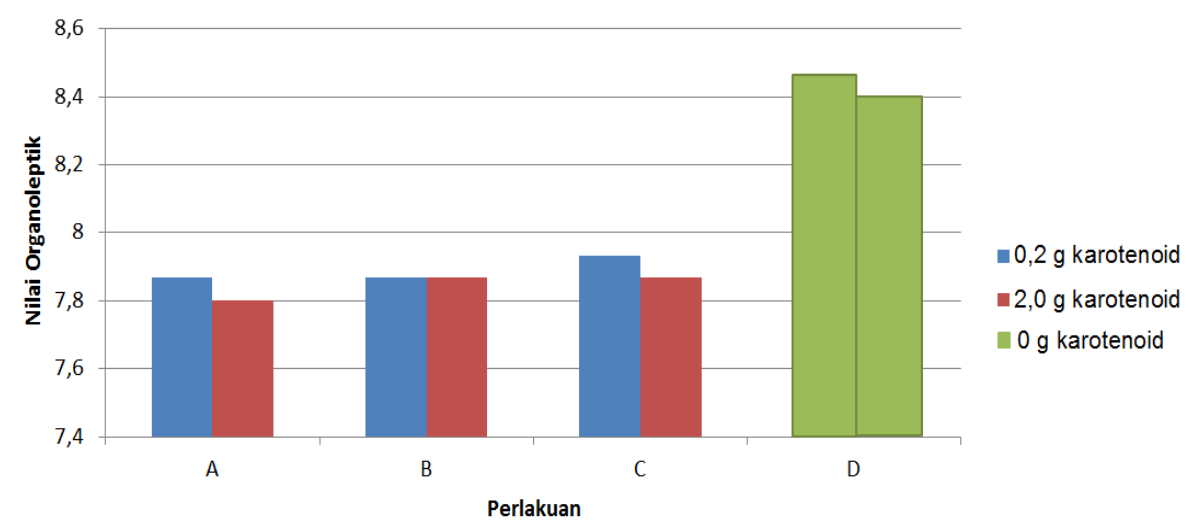

Gambar 2. Nilai Organoleptik Bau Bakso Ikan Nila dengan Penambahan Ekstrak Karoteoid dari Cangkang Udang (Perbandingan daging ikan: kanji, $A=70: 30, \quad B=60: 40, \quad C=50: 50, \quad D=70: 30$ tanpa karotenoid) 
Nilai bau bakso ikan nila dengan penambahan karotenoid dari cangkang udang dalam penelitian ini dikategorikan layak konsumsi sesuai dengan SNI 7266:2014 yang nilainya lebih besar dari 7 (> 7). Hal ini menandakan bahwa bakso ikan memiliki kriteria bau spesifik produk.

Bakso ikan yang bagus akan tercium bau spesifik ikan tanpa bau tambahan. Menurut Soekarto (1985) dalam Febiyando (2011), kelezatan suatu produk ditentukan oleh faktor aroma. Secara umum aroma menjadi daya tarik tersendiri dalam menentukan baik atau tidaknya suatu produk. Bakso ikan nila dengan penambahan ekstrak karotenoid memiliki aroma ikan bercampur udang yang khas dan juga aroma dari rempah-rempah yang ditambahkan pada pembuatan bakso ikan nila dengan penambahan karotenoid dari cangkang udang.

Hasil pengujian menggunakan uji anova dengan tingkat kepercayaan 95\% ( $\alpha=0.05)$ pada bau bakso ikan nila dengan proporsi daging ikan yang berbeda pada penambahan 0,2 g ekstrak karotenoid menunjukkan tidak ada perbedaan yang nyata (Lampiran 6). Begitupula pada penambahan 2,0 g ekstrak karotenoid tidak memberikan perbedaan yang signifikan (Lampiran 7). Pada hasil uji T test menunjukkan bahwa tidak ada pengaruh bakso pada proporsi daging dan kanji 70:30, 60:40 dan 50:50 terhadap penambahan rasio karotenoid 0,2 $\mathrm{g}$ dan 2,0 $\mathrm{g}$ pada bau bakso ikan nila. Meskipun tidak berpengaruh nyata, namun pada Gambar 2 menunjukkan perbedaan signifikan antara bakso yang menggunakan ekstrak karotenoid dan tidak menggunakan ekstrak karotenoid. Jika dilihat dari penilaian panelis, level bau bakso ikan nila yang tidak ditambahkan ekstrak karotenoid dari cangkang udang lebih tinggi dibandingkan yang menggunakan ekstrak karotenoid. Penggunaan ekstrak karotenoid cangkang udang cukup memberikan dampak buruk terhadap bau bakso ikan yang dihasilkan.

\section{Rasa}

Penilaian rasa dilakukan dengan mencicipi bakso kemudian dirasakan cita rasanya. Gambar 3 menunjukkan nilai organoleptik pada rasa bakso ikan nila dengan penambahan ekstrak karotenoid dari cangkang udang berkisar antara 8.13-8.33. Nilai terendah ditemukan pada proporsi daging ikan nila $70 \%$ tidak menggunakan karotenoid sedangkan untuk nilai tertinggi pada proporsi daging ikan nila $70 \%$ dan proporsi daging ikan nila 50\% menggunakan karotenoid. Nilai rasa pada produk hasil penelitian memiliki nilai lebih dari 8 (>8) menunjukkan bahwa bakso ikan 
memiliki kriteria rasa spesifik produk sesuai dengan dengan SNI 7266:2014.

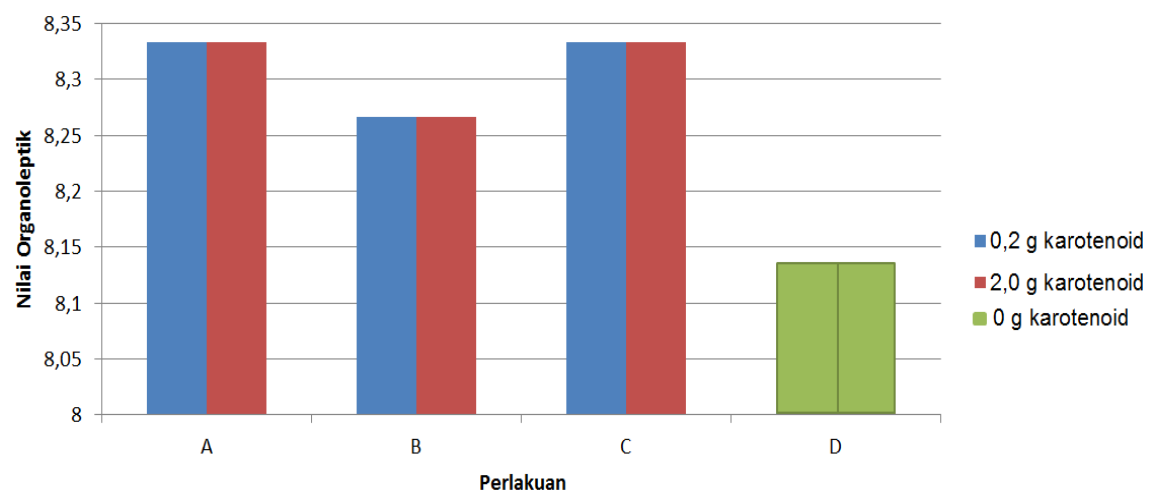

Gambar 3. Nilai Organoleptik Rasa Bakso Ikan Nila dengan Penambahan Ekstrak Karoteoid dari Cangkang Udang (Perbandingan daging ikan:kanji, $A=70: 30, B=60: 40, C=50: 50, D=70: 30$ tanpa karotenoid)

Rasa merupakan parameter paling proporsi daging ikan yang berbeda pada penting bagi konsumen untuk menentukan menerima atau menolak suatu produk. penambahan 0,2 g ekstrak karotenoid tidak Meskipun parameter yang lain dinilai cukup baik, tapi jika rasanya tidak enak atau tidak disukai maka produk akan ditolak (Soekarto 1985 dalan Febiyando 2011). Jika dilihat dari penilaian panelis (Gambar 3) level rasa bakso ikan nila yang tidak ditambahkan ekstrak karotenoid dari cangkang udang lebih rendah dibandingkan yang menggunakan ekstrak karotenoid. Penggunaan ekstrak karotenoid cangkang udang cukup memberikan dampak yang baik terhadap rasa bakso ikan yang dihasilkan.

Berdasarkan uji anova dengan tingkat kepercayaan 95\% $(\alpha=0.05)$ ditemukan informasi bahwa rasa bakso ikan nila dengan berbeda nyata namun penambahan ekstrak karotenoid menghasilkan nilai rasa yang signifikan lebih baik dibandingkan bakso yang tidak diberi ekstrak karotenoid. Begitupula pada penambahan 2,0 $\mathrm{g}$ ekstrak karotenoid tidak memberikan perbedaan yang signifikan. Pada hasil uji T test menunjukkan bahwa tidak ada pengaruh bakso pada proporsi daging dan kanji 70:30, 60:40 dan 50:50 terhadap penambahan rasio karotenoid $0,2 \mathrm{~g}$ dan $2,0 \mathrm{~g}$ pada rasa bakso ikan nila (Lampiran 11).

\section{Tekstur}

Hasil dari uji organoleptik pada tekstur bakso ikan nila dengan penambahan ekstrak karotenoid dari cangkang udang dapat dilihat pada Gambar 4. 


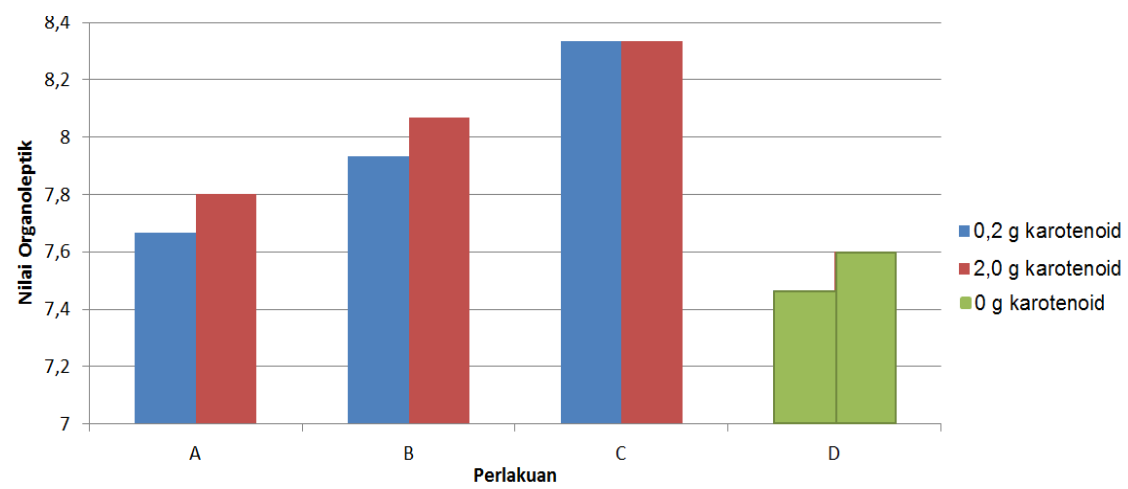

Gambar 4. Nilai Organoleptik Tekstur Bakso Ikan Nila dengan Penambahan Ekstrak Karoteoid dari Cangkang Udang

Gambar 4 menunjukkan bahwa nilai organoleptik tekstur bakso ikan nila dengan penambahan ekstrak karotenoid dari cangkang udang berkisar antara 7.47-8.33. Nilai terendah ditemukan pada proporsi daging ikan nila $70 \%$ tidak menggunakan karotenoid sedangkan untuk nilai tertinggi pada proporsi daging ikan nila $50 \%$ menggunakan $0,2 \mathrm{~g}$ dan $2,0 \mathrm{~g}$ karotenoid. Nilai tekstur pada produk hasil penelitian memiliki nilai lebih dari $7 \quad(>7)$ menunjukkan bahwa bakso ikan memiliki kriteria tekstur padat, kompak, agak kenyal sesuai dengan SNI 7266:2014.

Penurunan proporsi ikan nila diikuti oleh penambahan proporsi tepung kanji. Penambahan proporsi tepung kanji berdampak pada peningkatan pembentukan kompleks amilosa dan lemak dalam butiran granula tapioka yang rusak selama pemanasan, granula tepung akan membengkak secara keseluruhan dan granula ini menyerap lebih banyak air dan membuat gel lebih mudah rigid ketika mengalami pendinginan sehingga tekstur menjadi lebih keras (Noranizan et al. 2010).
Proporsi daging ikan paling bagus tedapat pada daging ikan nila dengan proporsi daging 50\% dan kanji 50\%.

Hasil pengujian menggunakan analisis uji anova dengan tingkat kepercayaan 95\% ( $\alpha=$ 0.05) menunjukkan tekstur bakso ikan nila dengan proporsi daging ikan yang berbeda pada penambahan 0,2 g ekstrak karotenoid berbeda nyata. Berdasarkan pengujian lanjutan yang dilakukan (uji tukey) ditemukan bahwa perbedaan nyata ditemukan pada bakso dengan proporsi daging $50 \%$ menggunakaan ekstrak karotenoid dan bakso dengan proporsi daging $70 \%$ yang tidak menggunakan karotenoid (Lampiran 12). Begitupula pada penambahan 2,0 $\mathrm{g}$ ekstrak karotenoid memberikan perbedaan yang signifikan. Dari uji lanjutan (uji tukey) ditemukan bahwa adanya perbedaan nyata bakso dengan proporsi daging 50\% menggunakaan ekstrak karotenoid terhadap bakso yang tidak menggunakan karotenoid. Pada hasil uji T test menunjukkan bahwa tidak ada pengaruh bakso pada proporsi daging dan kanji 70:30, 60:40 
dan 50:50 terhadap penambahan rasio karotenoid 0,2 $\mathrm{g}$ dan 2,0 g pada tekstur bakso ikan nila.

Secara keseluruhan, uji organoleptik menunjukkan bahwa level bakso yang menggunakan ekstrak karotenoid cangkang udang lebih tinggi dibandingkan yang tidak menggunakan ekstrak karotenoid cangkang udang. Bakso ikan nila dengan penambahan ekstrak karotenoid cangkang udang yang menggunakan 50\% daging ikan nila menggunakan karotenoid cangkang udang lebih tinggi daripada perlakuan lain (Gambar $5)$.

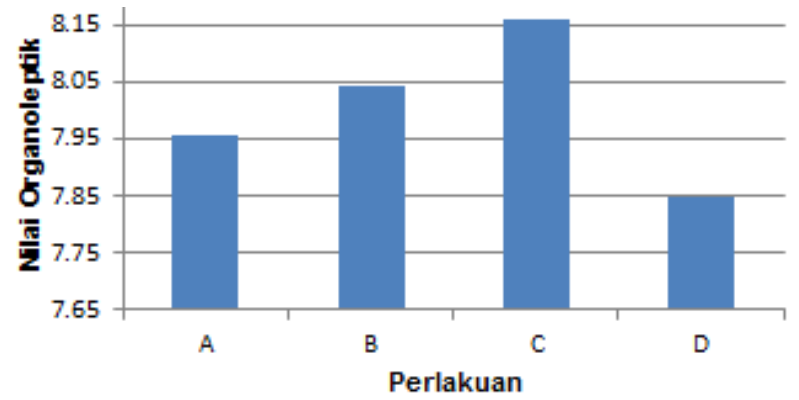

Gambar 5. Hasil Uji Total Organoleptik terhadap Bakso Ikan Nila dengan Penambahan Ekstrak Karotenoid Cangkang Udang (Perbandingan daging ikan:kanji, $A=70: 30, \quad B=60: 40$, $C=50: 50, D=70: 30$ tanpa karotenoid)
Peningkatan nilai organoleptik sejalan dengan peningkatan proporsi tepung kanji terutama disebebkan oleh dua hal:1). Daging ikan nila memiliki aroma yang kuat sehingga proporsi kanji yang lebih tinggi akan menetralisir aroma spesifik ikan nila; 2). Proporsi tepung kanji yang lebih tinggi menghasilkan tekstur bakso ikan nila yang lebih kenyal. Aroma atau citarasa dan tekstur merupakan parameter kunci yang menentukan kualitas organoleptik dari bakso.

\section{B. Kualitas Kesukaan Bakso Ikan Nila}

Parameter kesukaan yang diuji pada penelitian ini meliputi uji kenampakan, bau, rasa, tekstur, dan warna.

\section{Kenampakan}

Hasil dari uji hedonik / kesukaan pada kenampakan bakso ikan nila dengan penambahan ekstrak karotenoid dari cangkang udang dapat dilihat pada Gambar 6 .

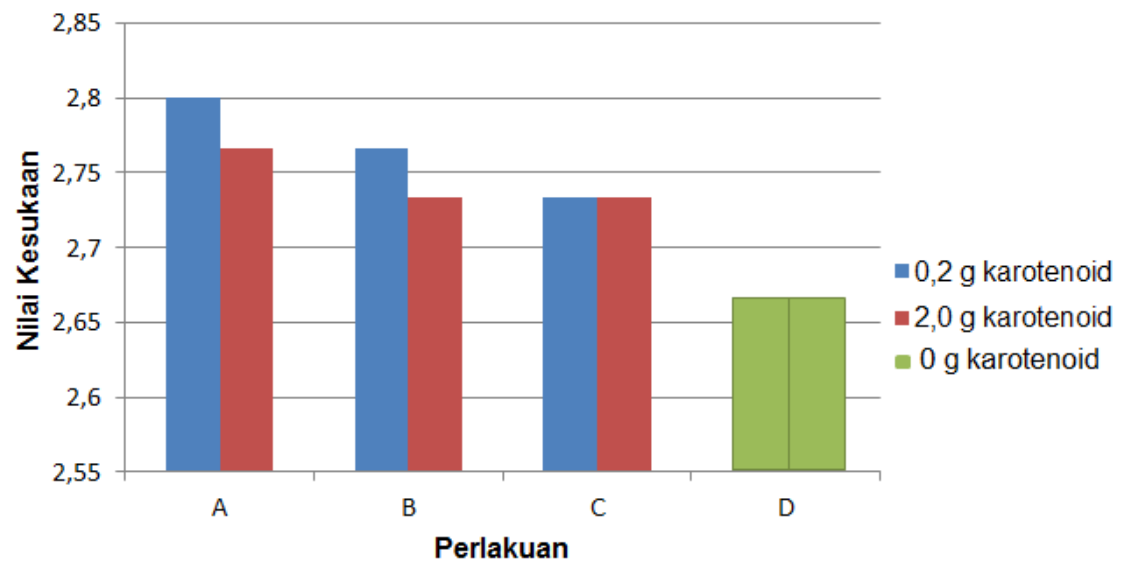

Gambar 6. Nilai Kesukaan pada Kenampakan Bakso Ikan Nila dengan Penambahan Ekstrak Karotenoid Cangkang Udang Perbandingan daging ikan: kanji, $A=70: 30, B=60: 40, C=50: 50, D=70: 30$ tanpa karotenoid) 
Gambar 6 memperlihatkan bahwa nilai kesukaan pada kenampakan bakso ikan nila dengan penambahan ekstrak karotenoid dari cangkang udang berkisar antara 2.67-2.80. Nilai kesukaan yang terendah pada proporsi daging ikan nila $70 \%$ tidak menggunakan karotenoid sedangkan untuk nilai tertinggi pada proporsi daging ikan nila $70 \%$ menggunakan $0.2 \mathrm{~g}$ karotenoid. Menurut Dewi (2007), kenampakan bakso ikan yang baik haruslah berbentuk bulat halus, berukuran seragam, bersih, cemerlang dan tidak kusam. Bentuk bakso hasil penelitian bulat namun tidak bulat sempurna dan permukaannya kurang halus namun masih bisa diterima oleh panelis.

Hasil uji anova dengan tingkat kepercayaan 95\% ( $\alpha=0.05)$ menunjukkan bahwa kenampakan bakso ikan nila dengan proporsi daging ikan yang berbeda pada penambahan 0,2 g ekstrak karotenoid tidak berbeda nyata (Lampiran 15). Begitupula pada penambahan 2,0 g ekstrak karotenoid tidak memberikan perbedaan yang signifikan pada bakso ikan nila (Lampiran 16). Namun penambahan ekstrak karotenoid menghasilkan nilai kenampakan yang signifikan lebih baik dibandingkan bakso yang tidak diberi ekstrak karotenoid (Gambar 8). Pada hasil uji T test menunjukkan bahwa tidak ada pengaruh bakso pada proporsi daging dan kanji 70:30, 60:40 dan 50:50 terhadap penambahan rasio karotenoid 0,2 g dan 2,0 g pada kenampakan bakso ikan nila (Lampiran 17).

\section{Bau}

Hasil uji kesukaan pada bau bakso ikan nila dengan penambahan ekstrak karotenoid dari cangkang udang dapat dilihat pada Gambar 7.

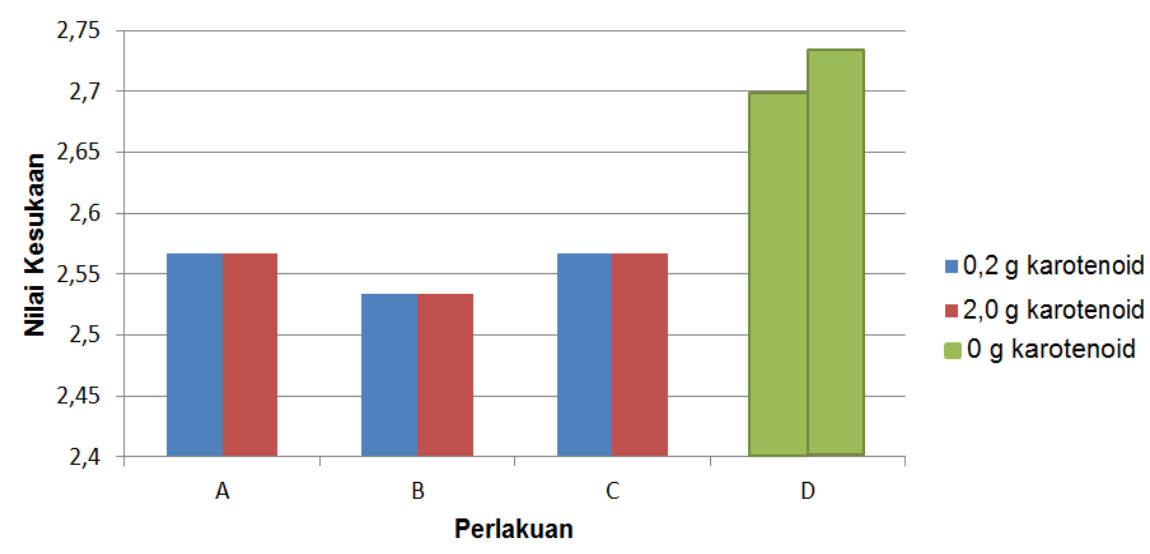

Gambar 7. Nilai Kesukaan pada Bau Bakso Ikan Nila dengan Penambahan Ekstrak Karotenoid Cangkang Udang (Perbandingan daging ikan: kanji, $A=70: 30, B=60: 40, C=50: 50, D=70: 30$ tanpa karotenoid)

Gambar 7 memperlihatkan bahwa nilai kesukaan pada bau bakso ikan nila dengan penambahan ekstrak karotenoid dari cangkang udang berkisar 2.53-2.73. Nilai terendah 
ditemukan pada percobaan dengan proporsi daging ikan nila $60 \%$ menggunakan $0,2 \mathrm{~g}$ dan $2,0 \mathrm{~g}$ karotenoid sedangkan untuk nilai tertinggi pada proporsi daging ikan nila 70\% tidak menggunakan karotenoid. Jika dilihat dari penilaian tingkat kesukaan, bisa dikatakan para panelis menyukai bau bakso ikan nila yang tidak ditambahkan ekstrak karotenoid dari cangkang udang. Penggunaan ekstrak karotenoid cangkang udang cukup memberikan dampak buruk terhadap bau bakso ikan yang dihasilkan yaitu percampuran antara bau ikan dan bau udang.

Hasil pengujian menggunakan uji anova dengan tingkat kepercayaan $95(\alpha=0.05)$ pada bau bakso ikan nila dengan proporsi daging ikan yang berbeda pada penambahan 0,2 g ekstrak karotenoid menunjukkan tidak ada perbedaan yang nyata (Lampiran 18). Begitupula pada penambahan 2,0 g ekstrak karotenoid tidak memberikan perbedaan yang signifikan (Lampiran 19). Pada hasil uji T test menunjukkan bahwa tidak ada pengaruh bakso pada proporsi daging dan kanji 70:30, 60:40 dan 50:50 terhadap penambahan rasio karotenoid $0,2 \mathrm{~g}$ dan 2,0 g pada bau bakso ikan nila (Lampiran 20).

\section{Rasa}

Hasil dari uji kesukaan pada rasa bakso ikan nila dengan penambahan ekstrak karotenoid dari cangkang udang dapat dilihat pada Gambar 8.

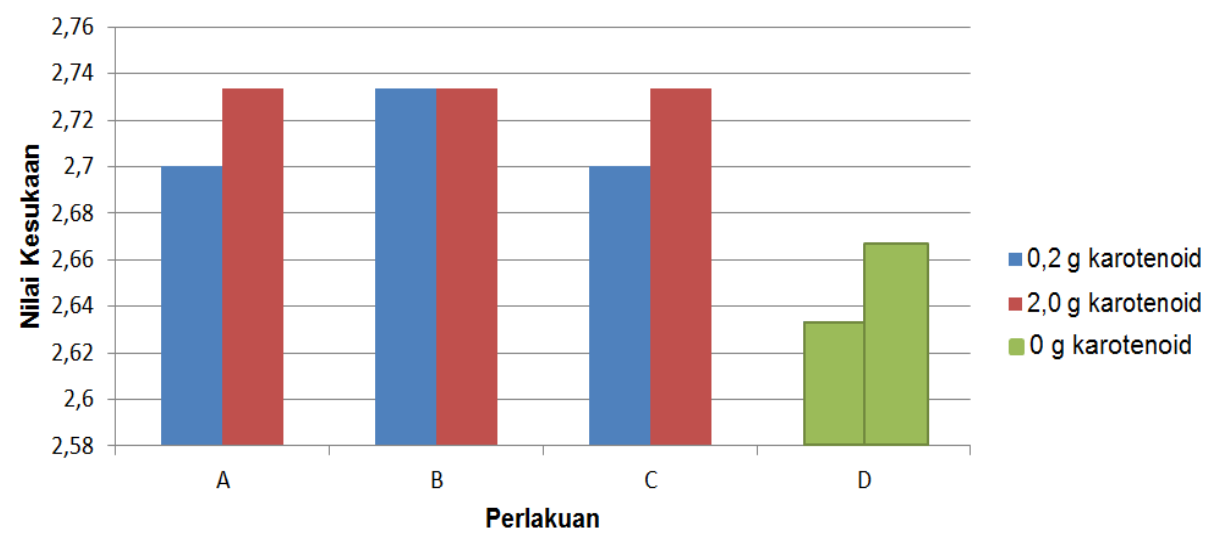

Gambar 8. Nilai Kesukaan pada Rasa Bakso Ikan Nila dengan Penambahan Ekstrak Karotenoid Cangkang Udang (Perbandingan daging ikan: kanji, $A=70: 30, B=60: 40, C=50: 50, D=70: 30$ tanpa karotenoid)

Menurut Dewi (2007) bakso ikan yang baik memiliki rasa ikan dominan sesuai jenis ikan yang digunakan dan rasa bumbu cukup menonjol tetapi tidak berlebihan, tidak terdapat rasa asing yang mengganggu dan tidak terlalu asin. Bakso ikan nila pada penelitian secara umum telah memenuhi kriteria tersebut, yaitu memiliki rasa ikan dan udang yang khas dan juga rasa dari rempahrempah yang cukup menonjol dan tidak terdapat rasa yang asing. Gambar 10 menunjukkan kesukaan pada rasa bakso ikan 
nila dengan penambahan ekstrak karotenoid dari cangkang udang berkisar antara 2.63-2.73. Nilai terendah ditemukan pada proporsi daging ikan nila $70 \%$ tidak menggunakan karotenoid. Panelis cenderung lebih menyukai bakso dengan penambahan ekstrak karotenoid daripada bakso yang tidak ditambahkan karotenoid.

Berdasarkan uji anova dengan tingkat kepercayaan 95\% ( $\alpha=0.05)$ dapat diketahui bahwa rasa bakso ikan nila dengan proporsi daging ikan yang berbeda pada penambahan 0,2 g ekstrak karotenoid tidak berbeda nyata namun penambahan ekstrak karotenoid menghasilkan nilai rasa yang signifikan lebih baik dibandingkan bakso yang tidak diberi ekstrak karotenoid (Lampiran 21). Begitupula pada penambahan 2,0 g ekstrak karotenoid tidak memberikan perbedaan yang signifikan (Lampiran 22). Pada hasil uji $T$ test menunjukkan bahwa tidak ada pengaruh bakso pada proporsi daging dan kanji 70:30, 60:40 dan 50:50 terhadap penambahan rasio karotenoid 0,2 g dan 2,0 g pada rasa bakso ikan nila (Lampiran 23).

\section{Tekstur}

Hasil dari uji kesukaan pada tekstur bakso ikan nila dengan penambahan ekstrak karotenoid dari cangkang udang dapat dilihat pada Gambar 9.

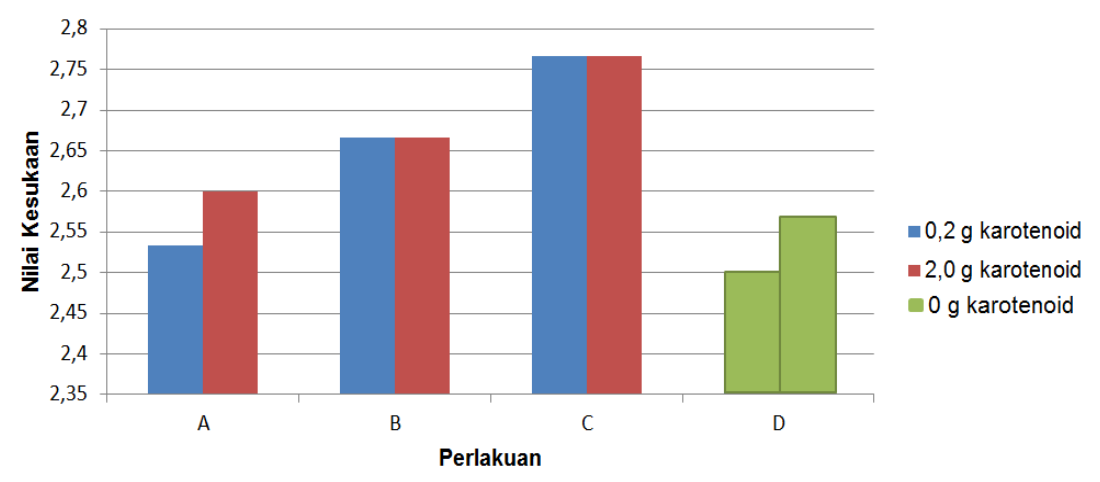

Gambar 9. Nilai Kesukaan pada Tekstur Bakso Ikan Nila dengan Penambahan Ekstrak Karotenoid Cangkang Udang (Perbandingan daging ikan: kanji, $A=70: 30, B=60: 40, C=50: 50, D=70: 30$ tanpa karotenoid)

Gambar 9 menunjukkan bahwa kesukaan pada tekstur bakso ikan nila dengan penambahan ekstrak karotenoid dari cangkang udang berkisar antara 2.50-2.76. Nilai terendah ditemukan pada proporsi daging ikan nila $70 \%$ tidak menggunakan karotenoid sedangkan untuk nilai tertinggi pada proporsi daging ikan nila 50\% menggunakan karotenoid. Kenaikan proporsi ikan nila diikuti oleh penurunan proporsi tepung kanji. Penilaian tekstur dilakukan dengan cara menekan-nekan permukaan bakso berdasarkan tingkat kekompakan, kekenyalan, dan kepadatan bakso. Menurut Soekarto (1985) dalam Febiyando (2011), terkadang tekstur lebih penting dibandingkan dengan aroma, rasa dan 
warna karena mempengaruhi citra makanan terutama pada produk fish-jelly seperti bakso dimana kekenyalan merupakan parameter yang sangat penting.

Hasil uji one way anova menunjukkan tekstur bakso ikan nila dengan proporsi daging ikan yang berbeda pada penambahan $0,2 \mathrm{~g}$ ekstrak karotenoid tidak berbeda nyata (Lampiran 24). Begitupula pada penambahan 2,0 g ekstrak karotenoid tidak memberikan perbedaan yang signifikan (Lampiran 25). Pada hasil uji T test menunjukkan bahwa tidak ada pengaruh bakso pada proporsi daging dan kanji 70:30, 60:40 dan 50:50 terhadap penambahan rasio karotenoid $0,2 \mathrm{~g}$ dan $2,0 \mathrm{~g}$ pada tekstur bakso ikan nila (Lampiran 26).

\section{Warna}

Hasil dari uji kesukaan pada warna bakso ikan nila dengan penambahan ekstrak karotenoid dari cangkang udang dapat dilihat pada Gambar 10.

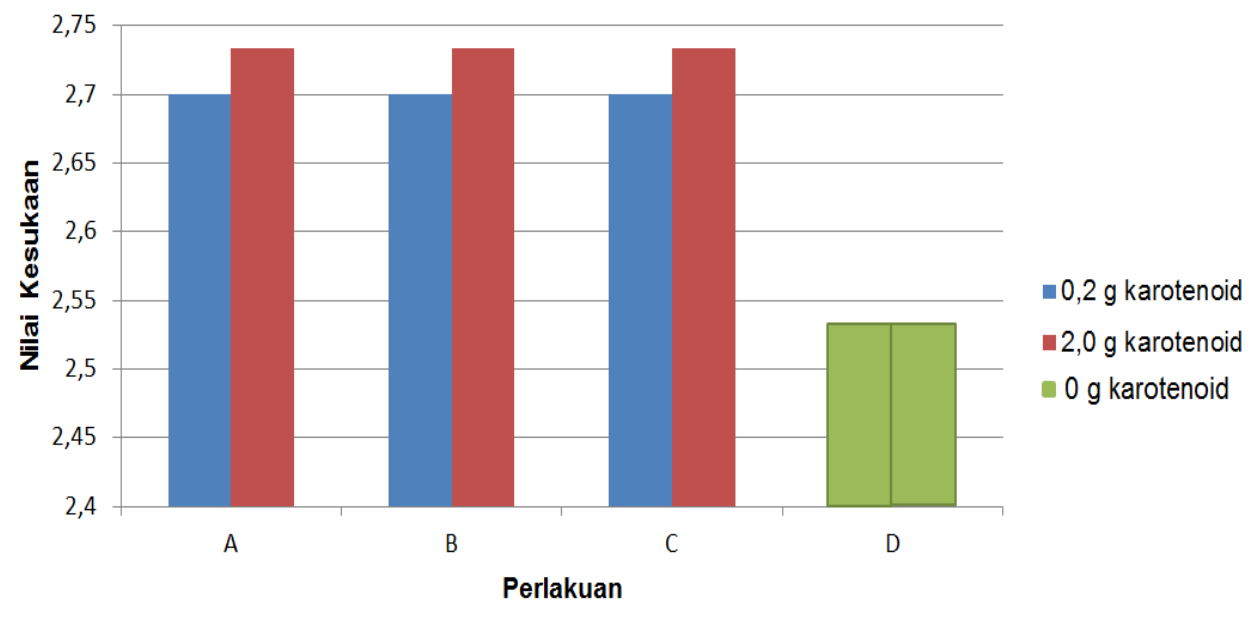

Gambar 10. Nilai Kesukaan pada Warna Bakso Ikan Nila dengan Penambahan Ekstrak Karotenoid Cangkang Udang (Perbandingan daging ikan: kanji, $A=70: 30, B=60: 40, C=50: 50, D=70: 30$ tanpa karotenoid)

Gambar 10 menunjukkan bahwa Gambar 10 juga dapat disimpulkan bahwa kesukaan pada warna bakso ikan nila dengan diantara penambahan karotenoid $0,2 \mathrm{~g}$ dan 2,0 penambahan ekstrak karotenoid dari cangkang udang berkisar antara 2.53-2.73. Nilai terendah ditemukan pada bakso yang tidak g, panelis lebih menyukai warna pada bakso yang ditambahkan 2,0 g ekstrak karotenoid menggunakan ekstrak karotenoid. Dari Gambar 10 dapat disimpulkan bahwa panelis lebih menyukai bakso yang ditambahkan ekstrak karotenoid yang berasal dari pigmen cangkang udang. Ekstrak katotenoid meningkatkan level artinya panelis lebih menyukai bakso yang lebih berwarna orange. Karotenoid merupakan pigmen yang memberikan warna kuning, orange atau merah pada ikan dan udang (Ciapara et al., 2006). Perbedaan warna antar percobaan dapat dilihat pada Gambar 11. penerimaan konsumen terhadap bakso. Dari 
Hasil pengujian menggunakan uji anova anova dengan tingkat kepercayaan 95\% ( $\alpha=$ 0.05) pada warna bakso ikan nila dengan proporsi daging ikan yang berbeda pada penambahan 0,2 g ekstrak karotenoid menunjukkan tidak ada perbedaan yang nyata (Lampiran 27). Begitupula pada penambahan
2,0 g ekstrak karotenoid tidak memberikan perbedaan yang signifikan (Lampiran 28). Pada hasil uji T test menunjukkan bahwa tidak ada pengaruh bakso pada proporsi daging dan kanji 70:30, 60:40 dan 50:50 terhadap penambahan rasio karotenoid $0,2 \mathrm{~g}$ dan $2,0 \mathrm{~g}$ pada bau bakso ikan nila (Lampiran 29).

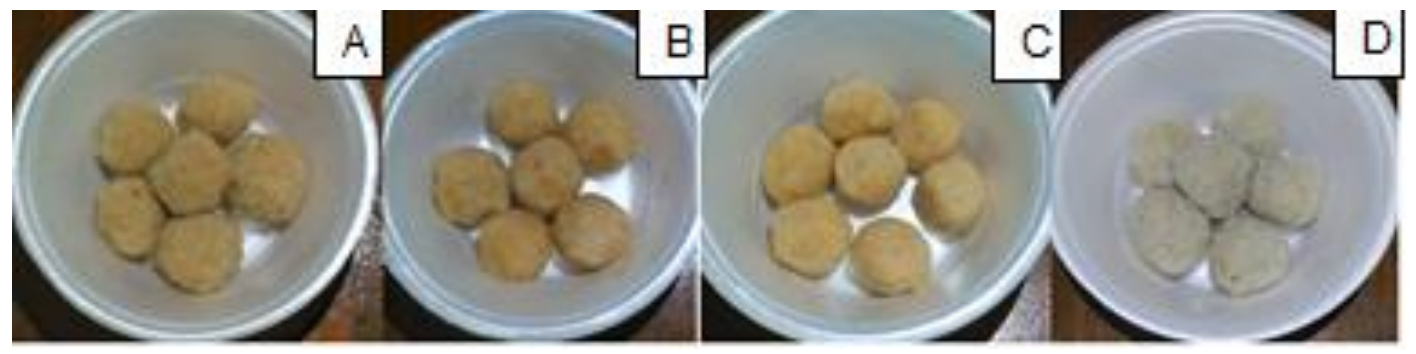

Gambar 11. Bakso Ikan Nila Percobaan I

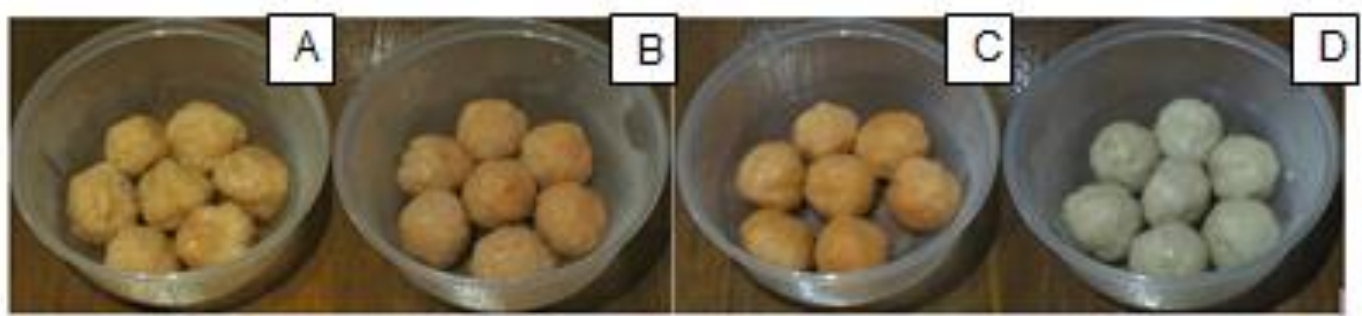

Gambar 12. Bakso Ikan Nila Percobaan II

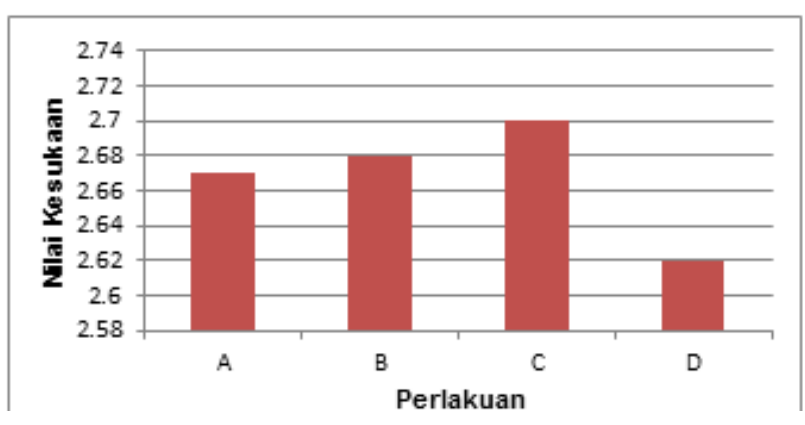

Gambar 13. Hasil Uji Total Kesukaan terhadap Bakso Ikan Nila dengan Penambahan Ekstrak Karotenoid Cangkang Udang (Perbandingan daging ikan:kanji, $A=70: 30$, $B=60: 40, \quad C=50: 50, \quad D=70: 30 \quad$ tanpa karotenoid)
Uji kesukaan menunjukkan panelis lebih menyukai bakso ikan nila dengan penambahan ekstrak karotenoid cangkang udang yang menggunakan 50\% daging ikan nila menggunakan karotenoid cangkang udang (Gambar 13). Gambar tersebut juga mempelihatkan bahwa penggunaan ekstrak karotenoid cangkang udang menghasilkan bakso ikan nila yang lebih disukai oleh panelis dibandingkan dengan bakso ikan nila yang tidak menggunakan karotenoid. 


\section{Uji Proksimat}

Hasil analisa proksimat bakso ikan nila dengan penambahan ekstrak karotenoid dari cangkang udang putih dapat dilihat pada Tabel 1.

Tabel 1. Komposisi Proksimat (\%) Bakso Ikan Nila dengan Penambahan Ekstrak Karotenoid dari Cangkang Udang

\begin{tabular}{ccccc}
$\begin{array}{c}\text { Kode } \\
\text { Sampel }\end{array}$ & Air & Protein & Lemak & Abu \\
\hline A & 61.67 & 7.83 & 0.13 & 1.09 \\
\hline B & 61.67 & 7.67 & 0.11 & 1.09 \\
\hline C & 61.67 & 7.43 & 0.11 & 1.09 \\
\hline D & 61.67 & 7.80 & 0.13 & 1.09 \\
\hline Keterangan: & & & &
\end{tabular}

$\mathrm{A}=70 \%$ proporsi daging ikan nila, 30\% tepung kanji dan karotenoid

$B=60 \%$ proporsi daging ikan nila, 40\% tepung kanji dan karotenoid

$\mathrm{C}=50 \%$ proporsi daging ikan nila, $50 \%$ tepung kanji dan karotenoid

$D=70 \%$ proporsi daging ikan nila, 30\% tepung kanji tanpa karotenoid

Dari penelitian ini diperoleh kadar air bakso ikan nila dengan penambahan ekstrak karotenoid dari cangkang udang sebesar 61,67\%. Nilai tersebut telah memenuhi persyaratan mutu produk bakso ikan, yaitu kadar air bakso ikan tidak lebih dari 65\%. Kadar protein menunjukkan penambahan proporsi daging ikan berakibat pada peningkatan kadar protein. Kadar protein pada sampel telah memenuhi persyaratan mutu produk bakso ikan, yaitu kadar protein bakso ikan tidak kurang dari 7\%. Kadar lemak bakso ikan nila yang dihasilkan dalam penelitian ini sangat rendah yaitu $0,11-0,13 \%$. Bakso ikan nila yang dihasilkan juga memiliki kadar abu yang seragam yaitu $1,09 \%$ dan kadarnya jauh dibawah nilai maksimum $2 \%$ yang ditetapkan sebagai standar mutu bakso ikan sesuai dengan SNI 7266:2014.

\section{KESIMPULAN}

Bakso ikan nila yang dibuat dalam penelitian ini memiliki mutu yang sesuai dengan Standar Nasional Indonesia (SNI 7266:2014). Penambahan ekstrak karotenoid meningkatkan kesukaan terhadap bakso ikan nila. Penambahan $50 \%$ daging ikan nila dan $50 \%$ tepung kanji dengan penambahan $2,0 \mathrm{~g}$ ekstrak karotenoid cangkang udang putih merupakan formulasi bakso ikan nila merupakan formulasi bakso ikan nila yang memiliki nilai dan tingkatan kesukaan yang paling tinggi.

\section{DAFTAR PUSTAKA}

Aditya. A.D. 2002. Mempelajari Karakteristik Bakso Ikan Nila (Oreochromis niloticus) dengan Penambahan Bubuk Flavor Dari Ekstrak Kepala Udang Windu (Paneus monodon). Skripsi: Program Studi Teknologi Hasil Perikanan. Fakultas Perikanan Dan Ilmu Kelautan. Institut Pertanian Bogor. Bogor

Astawan, M. 2004. Tetap Sehat Dengan Produk Makanan Olahan. Tiga Serangkai. Solo

Ciapara, H. Vanezuela, F. dan Goyocoolea, F. M. 2006. Astaxanthin: a review of its 
chemistry and applications. Critc. Rev. in Food Sci. and Nutr. 46:185-196

Fitria, N.C., Putut H.R., dan Ima, W. 2014. Pemanfaatan Karagenan (Euchema Cottoni) Sebagai Emulsifier terhadap Kestabilan Bakso Ikan Nila (Oreochromis nilotichus) pada Penyimpanan Suhu Dingin. Program Studi Teknologi Hasil Perikanan. Fakultas Perikanan dan Ilmu Kelautan. Universitas Diponegoro. Semarang

Kusnadi, B, dan Al Baarri. 2012. Daya ikat air, tingkat kekenyalan dan kadar protein pada bakso kombinasi daging sapi dan daging kelinci. Jurnal Aplikasi Teknologi Pangan.Surakarta

Montolalu, S. 2013. Sifat fisiko-kimia dan mutu organoleptik bakso broiler dengan menggunakan tepung ubi jalar (Ipomoea batatas L). Jurnal Zootek, Vol 32 No. 5, Januari 2013

Noranizam, M. A., Dzulkifly, M.H and Rusly, A.R. 2010. Effect of heat treatment on the physico-chemical properties of strarch from different botanical sources. International Food Research Journal 17:127-135

Permadi dan Dharmayanti. 2011. Modul Pengolahan Ikan Nila. Sekolah Tinggi Perikanan. Jakarta 44 hal.

Permatasari dan Wina A. 2002. Kandungan Gizi Bakso Campuran Daging Sapi Dengan Jamur Tiram (Pleuotus ostreatus) pada Taraf yang Berbeda. Skripsi: Jurusan Ilmu Produksi Ternak. Fakultas Peternakan. Institut Pertanian Bogor. Bogor

Romi. 2009. Analisis Proksimat. https://www.scribd.com/doc/18185685/a nalisis-proksimat. Diakses pada 17 Juni 2018

Saanin, H. 1982. Taksonomi dan kunci identifikasi ikan. Bina Cipta. Jakarta

Samsuar, 2006. Karakteristik karaginan Rumput laut Eucheuma cottonii Pada Berbagai Umur panen, Konsentrasi $\boldsymbol{K O H}$ dan Lama Ekstraksi. Tesis. Sekolah PascaSarjana Institut Pertanian Bogor. Bogor Sentra Informasi

Sitti, S. dan Murniana. 2009. Aktivitas Antioksidan Astaxanthin dari Limbah Kulit Udang. Laporan Penelitian: Fakultas Matematika dan Ilmu Pengetahuan Alam. Universitas Syiah Kuala. Banda Aceh

Standar Nasional Indonesia. 2014. Bakso Ikan. SNI 7266-2014. Badan Standarisasi Nasional. Jakarta

Standar Nasional Indonesia. 1995. Bakso Ikan. SNI 01-3819-1995. Badan Standarisasi Nasional. Jakarta

Suprapti, M. L. 2003. Membuat Bakso Daging dan Bakso Ikan. Kanisius. Yogyakarta

Suyanto. 2003. Pembenihan dengan Pembesaran Nila. Penebar Swadaya. Jakarta

Waridi. 2004. Pengolahan Bakso Ikan. Departemen Pendidikan Nasional. Jakarta

Widyaningsih, M. 2006. Alternatif Pengganti Formalin Pada Produk Pangan. Trubus Agrisarana. Surabaya

Winarno, F.G., 1996, Teknologi Pengolahan Rumput Laut. Pustaka Sinar Harapan, Jakarta. 